\title{
Corruption and Growth: Evidence from the Italian Regions
}

Nadia Fiorino, University of L'Aquila, Italy

Emma Galli, 'La Sapienza' University of Rome, Italy

Ilaria Petrarca, University of Verona, Italy *

\begin{abstract}
This paper investigates the impact of corruption on economic growth in the Italian regions. We estimate a dynamic growth model for the period 1980-2004 addressing both the potential bias of the measures of corruption and the endogeneity between corruption and economic development. We find strong evidence of a negative correlation between corruption and growth. Moreover, since government intervention has been traditionally used to reduce income differentials between the northern and the southern regions, we also analyse the interaction between corruption and government expenditure. Our results indicate that corruption undermines the positive impact that public expenditures have on economic growth.
\end{abstract}

\section{JEL Classification}

$\mathrm{H} 11 ; \mathrm{O} 40 ; \mathrm{O} 38$

\section{Keywords}

Corruption; associative crimes; economic growth; dynamic estimation

*Address for correspondence: ilaria.petrarca@univr.it. 


\section{Introduction}

Does corruption 'sand' or 'grease the wheels' of economic development? For a long time, scholars have investigated the economic consequences of corruption, drawing an ambivalent picture: on the one hand, corruption promotes investments that would have been otherwise stalled by regulations and bureaucratic procedures; on the other, it reduces the incentives to invest in productive activities. Therefore, the effect of corruption on growth remains an empirical question.

We contribute to this debate by estimating the effect of corruption on economic growth in a panel dataset for the 20 Italian regions during the period 1980-2004 to verify whether corruption played a role in the differentiated growth path of southern Italy. Italy is an interesting case in this perspective because regional inequalities still persist although different kinds of public policies have tried to reduce the per capita income differentials between the northern and the southern regions since the end of World War II (see Padovano, 2007). The distribution of corruption and of social capital across the country is not homogeneous even though the institutions and the policies aimed at punishing and preventing corruption are centralized at the national level, and this may contribute to explain the differences in the economic growth rates of the Italian regions.

So far the literature has not paid much attention to the Italian case, mainly due to the low quality of available data until the very recent years. Del Monte and Papagni (2001) investigated the link between corruption and economic growth in the Italian regions for the period 1963-1991. They show that the efficiency of public investments is lower in regions where corruption is higher which in turn negatively affects economic growth. We re-address this issue for a more recent period of the Italian history (1980-2004) characterised by high variability in both growth rates and corruption crimes. We use a newly assembled dataset which has the advantage of collecting economic, socio-demographic and politico-institutional variables at regional level and provide a methodological solution to the shortcomings of the commonly used measures of corruption. We also move a step forward with respect to the existing literature by using an estimation technique which reduces the endogeneity bias of the coefficients.

The rest of the paper is organized as follows. Section 2 reviews the literature on the nexus between corruption and economic growth; Section 3 describes the institutional context of the Italian regions and shows the time dynamics of our key variables, namely economic growth and corruption. In Section 4 we formulate our empirical strategy, present the empirical model and discuss the results. The last section provides some concluding remarks.

\section{Literature review}

Many economists consider corruption as a major obstacle to economic growth (see, among others, Myrdal, 1989; Andvig and Moene, 1990; Shleifer and Vishny, 1993; Blackburn et al., 2006). The main argument is that a government official that controls the supply of an individually-demanded service may abuse his arbitrary power to restrict the supply, for example, denying or delaying permissions. The elimination of these barriers requires an extra-price of the service, i.e. a bribe that increases the bureaucrats' rent. Nonetheless, the bribe removes also any incentive to invest and defines a sub-optimal rent-seeking equilibrium of human capital that hampers growth. Mauro (1995), Keefer and Knack (1997), Hall and Jones (1999), La Porta et al. (1999), Li et al. (2000) and Gyimah - Brempong (2002) estimate the impact of corruption on growth for a wide cross - section of countries. They verify that higher levels of corruption significantly reduce both investment and economic growth. Interestingly, larger levels of corruption are associated to a misallocation of public resources. Mauro (1998), Tanzi and Davoodi (1998), Gupta et al. (2001), Baldacci et al. (2004) find that corruption distorts the composition of government 
expenditure towards less productive activities and creates large public sectors where resources are wasted through rent seeking.

Some scholars, on the other hand, argue that corruption is not a totally inefficient activity because in the short run it solves some government failures (Leff , 1964; Huntinghton, 1968). This 'greasing the wheels' hypothesis, however, limits the growth-enhancing effect of corruption to those situations where governance is lacking and/or economic policy is inefficient. Lui (1985) formalizes this argument into a model where firms value the time to waste in a queue. The more productive firms want to waste as little time as possible in the queue; therefore they are willing to buy the priority of their activities by paying a bribe. Along this line of research Shleifer and Vishny (1994) develop a model of bargaining between politicians and enterprises and show that corruption can facilitate an efficient allocation of resources. This is because bribes are a way to distribute wealth between politicians and agents in the private sector. In other words, corruption increases efficiency by allowing private sector agents to buy their way out of the inefficiencies that would otherwise be introduced by the politicians. In this perspective, the existence of a negative linear relationship between corruption and growth is challenged in favour of a non-linear one, which predicts a positive growth effect at low levels of corruption incidence (see, among others, Kurrild-Klitgaard, 1988 and Acemoglu and Verdier, 1998).

The 'greasing the wheels hypothesis' also implies that the relationship between corruption and economic growth can be affected by both the quality of the institutions and the size of the public sector. Ehrlich and Lui (1999) develop an endogenous growth model that analyzes the effect of corruption on economic growth in different politico-institutional settings. They predict that the balanced growth in a democracy (or competitive regime) and in an autocracy (or monopolistic regime) is the outcome of interaction between accumulation of human capital (socially productive) which engenders growth, and accumulation of political capital (socially unproductive) which mainly assures bureaucratic power and potential corruption. A non-linear relationship between corruption and growth is empirically found only in democratic regimes. Méndez and Sepulveda (2006) distinguish between 'free' and 'not-free' countries and include a measure of government expenditures to capture its interaction with corruption. Their findings show that in 'free' countries corruption results beneficial for economic growth at low levels of incidence and detrimental at high levels of incidence. This relationship is not modified by the size of government.

\section{Economic growth and corruption in the Italian regions: some stylized facts}

\section{The institutional framework}

Italy is divided into 20 regions, that represent the upper tier of sub-state government. Five of them, established in the years between 1948 and 1963, enjoy a special statute (Regioni a Statuto Speciale, or RSS) because of their multilingual status and peculiar geographical and economic position. The other 15 regions, featuring an ordinary statute (Regioni a Statuto Ordinario, or RSO), were established in the 1970s. Until mid-1990s, however, the regions heavily depended on the central government. In particular, they have expenditure autonomy but lacked tax autonomy; regional resources were represented by transfers from national taxes and grants from the central government, whose amounts were not modifiable by the regions. Since the 1990s, several legislative and constitutional reforms changed the institutional framework and increased both tax autonomy and expenditure competences. Currently regional governments levy taxes of their own (about $24 \%$ of total national fiscal revenue), as well as shares of national taxes and transfers (about 53\%) (Giardina et al, 2009), and are responsible for health care 
expenditure plus a share of social services, education, environment, local transportation, housing, culture and tourism. Differences in competences between the RSO and RSS have been reduced.

\section{Economic growth, corruption and associative crimes in the Italian regions}

Figure 1: Time dynamics of GDP growth and per capita corruption crimes

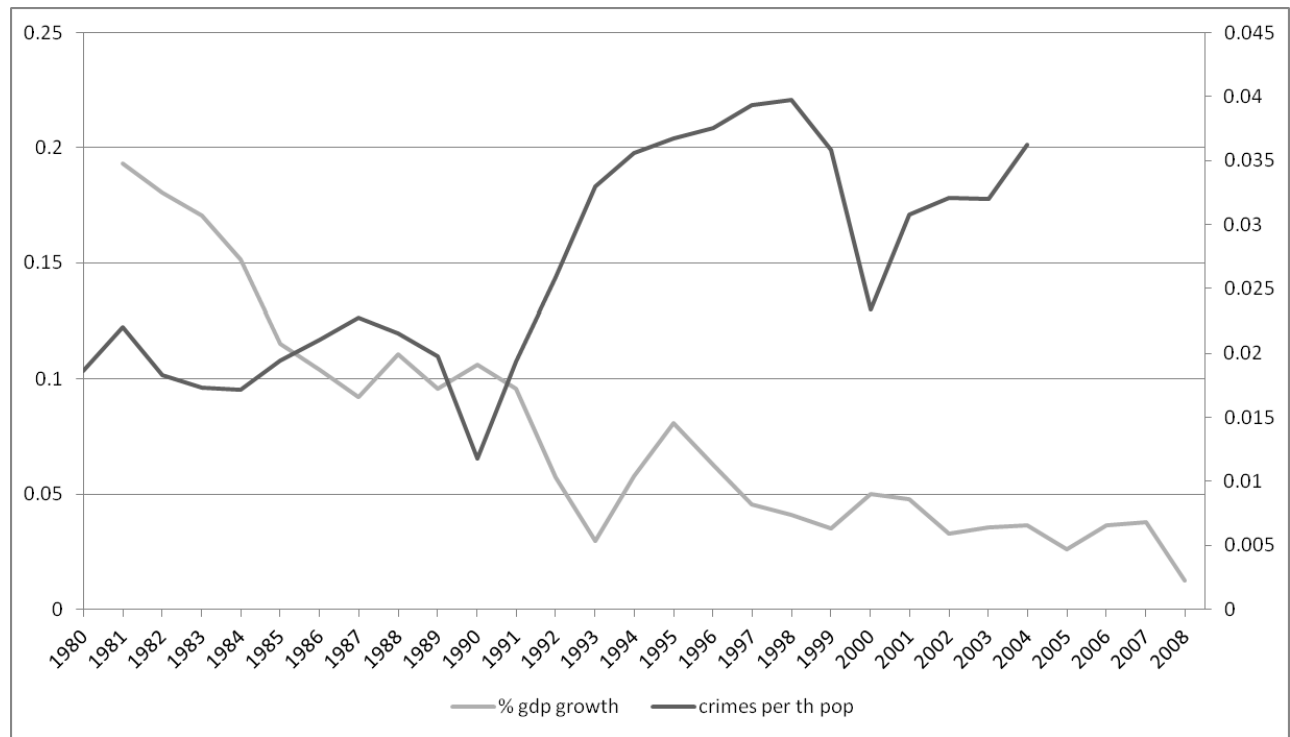

Yearly data are averaged over the full sample. GDP growth is measured as the percentage change from the past years' GDP growth; crimes are measured as per capita prosecutions for corruption crimes. Source: Italian Institute of Statistics (ISTAT)

Figure 1 illustrates an opposite trend in GDP growth and per capita prosecutions for corruption crimes. Overall economic growth decreased in Italy, with a significant fall in the early 90s. The growth rates always were under 5\% after 1997 while corruption crimes increase steadily between the mid-1970s and the first half of the 1990s and slightly decrease after 1993 as a consequence of the so-called Mani Pulite (Clean Hands) campaign undertaken by the judicial system. 
Figure 2. GDP growth (average annual data)

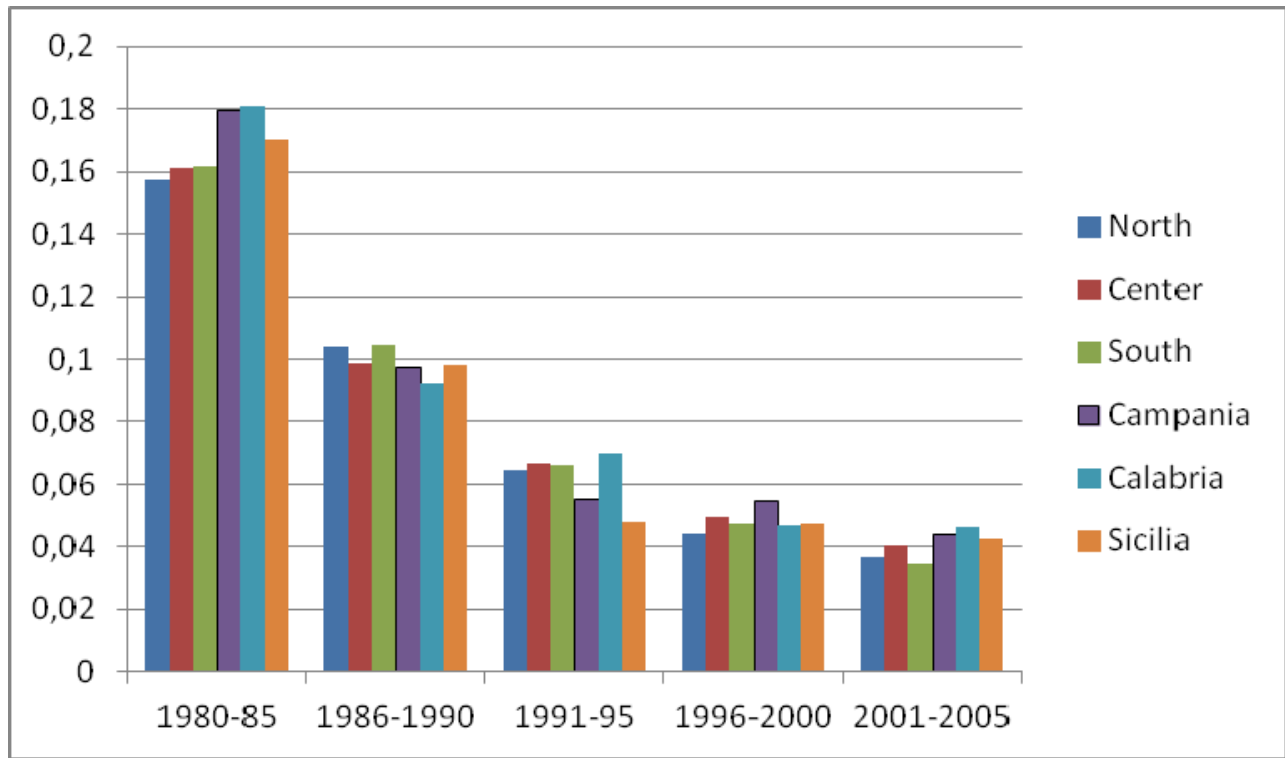

North: Piedmont, Val d'Aosta, Lombardy, Trentino-Alto Adige, Veneto, Friuli-Venezia Giulia, Liguria and Emilia Romagna; Centre: Tuscany, Umbria, Marche, Latium; South: Abruzzo, Molise, Apulia, Basilicata,

Sardinia.

Figure 2 shows that the level of GDP growth is quite homogeneous across the macro-areas, and displays a decreasing pattern during the period $1980-1995 .{ }^{1}$ Within the South an important difference between the regions characterized by a pervasive presence of criminal organizations and the others emerges, which seems to account for $10 \%$.

\footnotetext{
${ }^{1}$ Recently Daniele and Malanima (2007) describe the Mezzogiorno gap in GDP per capita between 1861 and 2004. While uniformity characterizes the pre-industrial period, since the 1880s a long divergence phase starts between the industrial areas and those which were not able to create a manufacturing industry. This phase ends in 1951 when the GDP per capita in the southern regions was only $47 \%$ of that of the rest of Italy, then the convergence process continued until the first half of the 1970 s when the relative GDP per capita reached about $66 \%$. During the 1980 s a new phase of a divergence process begins until 2002.
} 
Figure 3. Corruption crimes (average annual data)

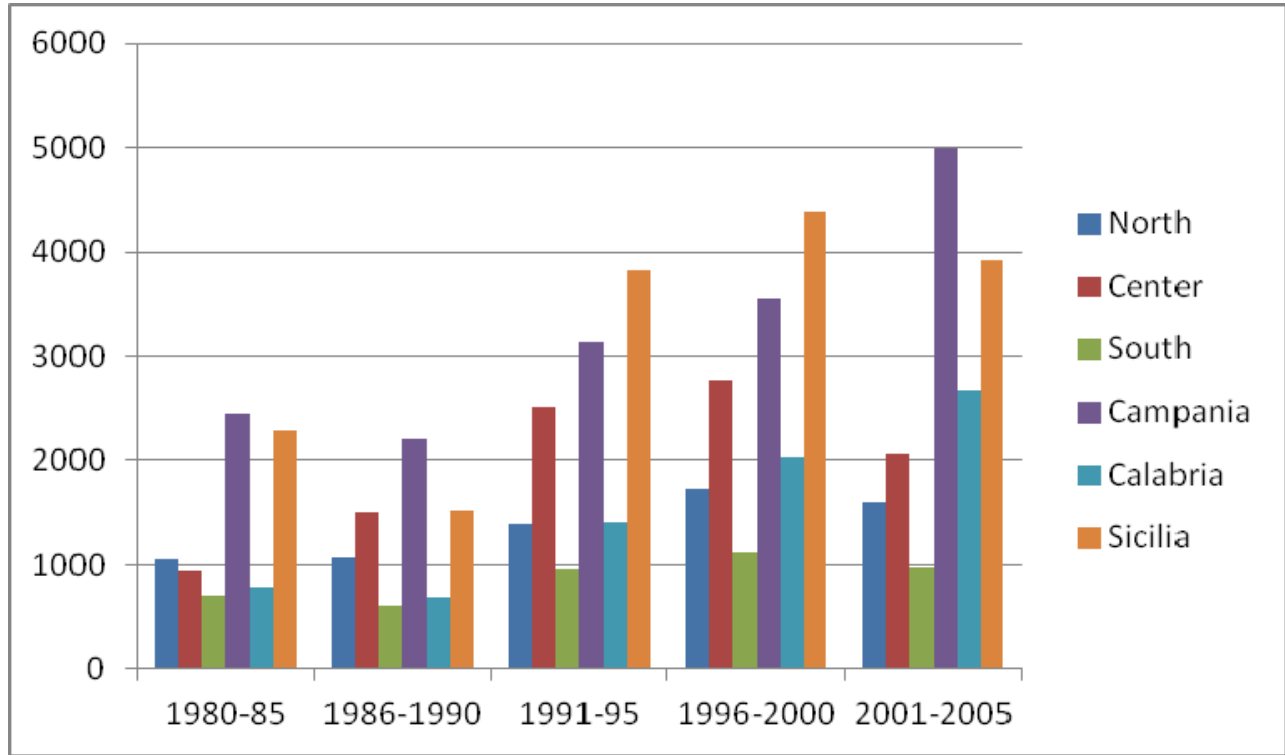

Note: North: Piedmont, Valle d'Aosta, Lombardy, Trentino-Alto Adige, Veneto, Friuli-Venezia Giulia, Liguria and Emilia Romagna; Center: Tuscany, Umbria, Marche, Latium; South: Abruzzo, Molise, Apulia, Basilicata, Sardinia.

Figure 3 shows that the number of corruption crimes decreases in the 1980s; a significant increase is recorded from 1991 to 1998 , where the number of crimes jumps from around 600 to around 2400; finally, after a decrease in 2000, it increased again. Sicily and Campania appear as the most corrupted regions of Italy, followed respectively by the northern, the central and the southern ones. 
Table 1. GDP and prosecutions per capita (1980-2004, average annual data)

\begin{tabular}{|c|c|c|c|c|c|}
\hline Region & GDP pc & Region & $\begin{array}{c}\text { Associative } \\
\text { crimes }\end{array}$ & Region & $\begin{array}{c}\text { Corruption } \\
\text { crimes }\end{array}$ \\
\hline Yollod'Aneto & & Sicily & 42.1 & Latium & 961 \\
\hline $\begin{array}{l}\text { Trentino-Alto } \\
\text { Adige }\end{array}$ & 20.159 & Calabria & 31.1 & Molise & 901.3 \\
\hline Lombardy & 19.715 & Campania & 30.6 & Valle d'Aosta & 787.9 \\
\hline $\begin{array}{l}\text { Emilia- } \\
\text { Romagna }\end{array}$ & 19.030 & Apulia & 21.4 & Liguria & 775.1 \\
\hline $\begin{array}{c}\text { PiedmontPied } \\
\text { mont }\end{array}$ & 17.53 & Basilicata & 18 & Calabria & 699.8 \\
\hline Veneto & 17.22 & Liguria & 15.6 & Sicily & 622 \\
\hline Tuscany & 16.54 & Latium & 15.2 & Sardinia & 617.2 \\
\hline $\begin{array}{l}\text { Friuli-Venezia } \\
\text { Giulia }\end{array}$ & 16.1875 & Abruzzo & 13.2 & $\begin{array}{c}\text { Friuli-Venezia } \\
\text { Giulia }\end{array}$ & 607.7 \\
\hline Latium & 16.07 & $\begin{array}{l}\text { Friuli-Venezia } \\
\text { Giulia } \\
\text { Fmilia- }\end{array}$ & 13.1 & Abruzzo & 601.2 \\
\hline Liguria & 15.79 & $\begin{array}{l}\text { Emilla- } \\
\text { Romagna }\end{array}$ & 12.1 & Campanıa & 558.2 \\
\hline Umbria & 14.79 & Umbria & 12.6 & Basilicata & 494 \\
\hline Marche & 14.47 & $\begin{array}{l}\text { Trentino-Alto } \\
\text { Adige }\end{array}$ & 11.7 & Tuscany & 494 \\
\hline Abruzzo & 12.54 & Lombardy & 11.6 & Apulia & 483.6 \\
\hline Sardinia & 11.44 & $\begin{array}{c}\text { Valle d'Aosta } \\
\text { Molise }\end{array}$ & $\begin{array}{l}11.4 \\
11.1\end{array}$ & $\begin{array}{c}\text { Trentino-Alto } \\
\text { Adige } \\
\text { Umbria }\end{array}$ & $\begin{array}{l}459.8 \\
456.7\end{array}$ \\
\hline $\begin{array}{l}\text { Molise } \\
\text { Sicily }\end{array}$ & $\begin{array}{l}11.001 \\
10.42\end{array}$ & & 10.9 & & 426.3 \\
\hline Basilicata & 9.68 & Tuscany & 10.8 & Marche & 393.8 \\
\hline Apulia & 9.61 & Piedmont & 10 & Lombardy & 375.3 \\
\hline $\begin{array}{c}\text { Campania } \\
\text { Calabria }\end{array}$ & $\begin{array}{l}9.56 \\
8.71 \\
\end{array}$ & $\begin{array}{l}\text { Marche } \\
\text { Sardinia }\end{array}$ & $\begin{array}{c}8 \\
6.8\end{array}$ & $\begin{array}{c}\text { Veneto } \\
\text { Emilia- } \\
\text { Romagna }\end{array}$ & $\begin{array}{l}374.6 \\
349.5\end{array}$ \\
\hline
\end{tabular}

Note: data are reported by descending order; per capita GDP is measured in thousands of euro; per capita crimes are measured per million of inhabitants. Source: Italian Institute of Statistics (ISTAT)

Overall, GDP growth as well as corruption crimes change both over time and across regions. Table 1 provides a ranking of the regions according to their average GDP and corruption crimes per capita. Using prosecution data as a measure for corruption bumps against the circumstance that in corrupt regions the judicial system is itself corrupt and fewer people will be charged with corrupt practices. The effectiveness of a legal system is rooted not only in the formulation of laws but also in the 'legal culture', that is the expectations and practices that inform the way they are enforced (Treisman, 2000).

Although the legal system is the same in all the Italian regions, its degree of legitimacy is not. Moreover, such a measure reflects only the 'revealed' corruption, most likely by leaving part of the phenomenon hidden. Table 1 highlights this problem. The northern regions are less corrupt than the central and southern regions; however, the ranking is not completely in line with people's common sense about the real distribution of corruption in Italy. Indeed, prosecutions for corrupt practices in the Appeal Court district of Reggio Calabria, one of the major towns of Calabria, in the last twenty years resulted in two convictions only. Nevertheless, similar conditions characterize the districts of other 'perceived' corrupt regions, like Sicily, Campania and Sardinia (Davigo and Mannozzi, 2007). To take into account the hidden corruption and avoid potential bias between official statistics and 'true' data, we consider the existing link between corruption and associative crimes (crimes ex art. 416 and 416 bis of the Italian Criminal Law). This 
implies that, as the so-called Mani Pulite criminal trials confirmed, corruption emerges not only as corrupt practices but also as associative crimes in the most 'perceived' corrupt regions.

\section{Empirics}

\section{Empirical strategy and model specification}

There are several issues related with the characteristics of the dataset that give reason for the choice of the estimator. First, the literature on corruption and growth generally estimates cross - sectional regressions by averaging the effect of temporary shocks and smoothing the cycling pattern of GDP. Although apparently straightforward, cross-country analyses make the implicit assumptions that countries are positioned on their steady state equilibria values for both the level of corruption and growth rate of output. Hence, averaging out data into a single observation for each region involves a loss of information and may also distort the analysis of the relationship between the two. Since the GDP growth rate as well as the corruption rate are not homogeneously distributed across regions and change over time, we employ a dynamic panel regression accounting also for the time variability of the data.

Secondly, our dependent variable, GDP growth, reasonably follows an autoregressive trend and requires a dynamic specification. The small size of the dataset, limited to at most 20 observations, reduces the efficiency of the GMM estimators (Arellano and Bond, 1991; Blundell and Bond, 1998) and requires a correction (Bruno, 2005a and 200b).

Another concern is related to data on prosecutions against corruption. This measure is problematic because a low rate of prosecutions may signal either a low effective incidence of corruption or a widespread hidden corruption. Moreover, it hits against the circumstance that in corrupt regions the judicial system may be itself corrupt and consequently fewer people would be charged with corruption crimes.

Further, potential endogeneity may affect the relationship between corruption and growth. An extensive literature originated by Lipset (1960) considers that low levels of income generally determine corruption, i.e. less developed regions are endemically more corrupt. If this is the case, corruption would be correlated with the error term in the OLS regression and the estimates would be biased. To control for the problem of a two-way causality between corruption and growth, we estimate an equation of determinants of corruption through OLS and insert the estimated fitted values of the parameters of interest in our dynamic growth equation (Kelejian, 1971; Petterson-Lidblom and Dahlberg, 2003). ${ }^{2}$ This procedure also allows us to take into account possible problems related to the quality of the legal system and the under-reporting. Indeed, the corruption equation controls for the degree of social capital which captures the existence of regional differences in people's general attitude towards corruption.

Based on these considerations we develop a two-step procedure. The first step estimates an equation of the determinants of corruption (see on this issue Fiorino and Galli, 2010). The fitted values obtained from this equation reduce the potential bias due to the heterogeneous distribution of social capital and quality of the legal system at regional level; moreover, the OLS estimation of this equation allows for

\footnotetext{
${ }^{2}$ Many authors have also worked with five-year averages for similar purposes. The use of five-year averages reduces short run fluctuations and allows to concentrate on the relationships between corruption and growth. See, for example, Li et al. (2000), Paldam (2002), Glaser and Saks (2006), Méndez and Sepulveda (2006).
} 
removing endogeneity in the growth model. ${ }^{3}$ The second step estimates a growth equation and substitutes the corruption crimes with the fitted values obtained in first step. To control for the dynamic bias induced we follow the literature and apply a Least Squares Dummy Variables Corrected model (LSDVC, Bruno 2005a and 2005b). This estimator corrects the LSDV estimator ${ }^{4}$ for the small size of the sample and provides a significant reduction of the bias, performing as well as the GMM estimator properly identified. ${ }^{5} \mathrm{~A}$ slight limitation of this methodology is the requirement of exogenous right hand side variables.

\section{Sample data and description of variables}

Our dataset collects economic, socio-demographic and politico-institutional variables for the 20 Italian regions during the period 1980-2004 and consists of 500 observations. The source, if not differently specified, is the Italian Institute of Statistics (ISTAT). The variables are summarized in Table 2.

\footnotetext{
${ }^{3}$ Petterson-Lidblom and Dahlberg (2003) show in fact that the use of the OLS estimates in the first stage allows us to obtain consistent estimates of the parameters of interest without the need to resort to the full blown functional form of the first stage.

${ }^{4}$ That is an OLS regression including regional dummies. We estimated also a set of LSDV uncorrected for the dynamic bias and obtain results consistent with the ones presented.

${ }^{5}$ An alternative dynamic estimator is the system GMM developed by Blundell and Bond (1998). This estimator adds to the equation in levels instrumented with differences (Arellano and Bond, 1991), a second equation in differences, instrumented with the variables in levels. When the GMM estimators are applied to small samples, the number of instruments outnumbers the observations, and overfit the lagged dependent variable. Instrument proliferation generates false positive results, reducing the reliability of the estimates. Roodman (2009) proposes to collapse the matrix of instruments to decrease their number. A rule of the thumb, however, suggests that to obtain robust test statistics one needs a number of instruments not larger than the number of groups. The GMM estimation of Equation 2 never satisfies the rule of thumb, as in the most parsimonious specification we use 23 instruments for 19 groups.
} 
Table 2. Descriptive statistics

\begin{tabular}{|c|c|c|c|c|c|}
\hline & Obs & Mean & Std. Dev. & Min & $\operatorname{Max}$ \\
\hline GDP growth & 484 & 0.084 & 0.051 & -0.003 & 0.257 \\
\hline \multicolumn{6}{|l|}{$\begin{array}{l}\text { VARIABLES OF } \\
\text { INTEREST: } \\
\text { CORRUPTION } \\
\text { COR, Individual }\end{array}$} \\
\hline $\begin{array}{l}\text { crimes per } \\
\text { pop }\left({ }^{*} 1000\right) \\
\text { ASCR, }\end{array}$ & 500 & 0.572 & 0.308 & 0.10 & 1.939 \\
\hline $\begin{array}{l}\text { Associative } \\
\text { crimes per } \\
\text { pop }\left({ }^{*} 1000\right)\end{array}$ & 520 & 0.016 & 0.015 & 0 & 0.226 \\
\hline Expenditure/GDP & 456 & 0.46 & 6.127 & 0.003 & 130.992 \\
\hline $\begin{array}{c}\text { Current } \\
\text { expenditure/GDP }\end{array}$ & 444 & -2.507 & 0.359 & -3.355 & -1.306 \\
\hline $\begin{array}{c}\text { Capital } \\
\text { expenditure/GDP }\end{array}$ & 444 & -3.719 & 1.03 & -5.870 & -1.199 \\
\hline $\begin{array}{c}\text { Investments/GDP } \\
\text { lag }\end{array}$ & 460 & 0.067 & 0.024 & 0.029 & 0.197 \\
\hline $\begin{array}{c}\text { Public } \\
\text { consumption/GD } \\
\text { P }\end{array}$ & 480 & 0.217 & 0.057 & 0.118 & 0.358 \\
\hline Gini index & 440 & 0.33 & 0.035 & 0.236 & 0.479 \\
\hline $\begin{array}{l}\text { School } \\
\text { attainment }\end{array}$ & 454 & 0.046 & 0.007 & 0.02 & 0.065 \\
\hline Labor force units & 500 & 1150.13 & 971.99 & 56.8 & 4508.7 \\
\hline Population & 576 & 2874227 & 2259821 & 112262 & 9742676 \\
\hline Number of laws & 460 & 50.25 & 26.40 & 3 & 165 \\
\hline Fragmentation & 460 & 0.668 & 0.13 & 0.128 & 0.880 \\
\hline $\begin{array}{c}\text { Voluntary } \\
\text { organizations }\end{array}$ & 460 & 449 & 555 & 11 & 5362 \\
\hline $\begin{array}{l}\text { Diffusion of } \\
\text { newspapers }\end{array}$ & 580 & 231811 & 221249 & 5687 & 1098279 \\
\hline $\begin{array}{c}\text { Referendum } \\
\text { voters }\end{array}$ & 460 & 1428645 & 1283230 & 31059 & 6177641 \\
\hline
\end{tabular}

Our first step consists in estimating an equation of the determinants of corruption. The equation is defined as follows:

[1] CORRUPTIONit $=f\left(X_{i t}, e_{i t}\right)$

for $i=1, \ldots, 20$ and $t=1980, \ldots, 2004$, where $X$ is a vector of explanatory variables and $\mathrm{e}$ is the error term.

We measure CORRUPTION in two different ways: 1) the number of regional government officials prosecuted for corrupt practices relative to the population (COR). The crimes that we consider are based on the Libro II, Titolo II (crimes against the Public Administration) of the Italian Criminal Law as reported in the Annali di Statistiche Giudiziarie of the ISTAT (various issues). 2) A composite index annually computed per each region as the sum of per capita prosecutions and per capita associative crimes (COR+ASCR). This because the most important criminal trials against corruption in Italy (the so-called Mani Pulite and Maxi Trial of the Sicilian mafia) have confirmed that corrupt activities may emerge also in the form of other typologies of crimes like the associative crimes (crimes ex art. 416 and 416 bis of the Italian Criminal Law) that cannot be strictly considered crimes of corruption.

The explanatory variables are: 
a) Population in millions of inhabitants, a proxy for the size of the region. If highlypopulated regions exploit economies of scale in supplying of public goods (Alesina and Wacziarg, 1997) and have a low ratio of public service outlets per population, individuals might revert to bribes to 'get ahead of the queue'.

b) GDP growth is the annual growth of GDP per capita calculated starting from the yearly GDP data released by CRENOS (2004). The growth is defined as the ratio between the first difference and the lagged GDP, representing the percentage of shift from the previous year's aggregate output. Thus, GDPgrowth ${ }_{\text {it }}=\left(G P_{i t}\right.$ $\left.\mathrm{GDP}_{\mathrm{i}, \mathrm{t}-1}\right) / \mathrm{GDP}_{\mathrm{i}, \mathrm{t}-1}$. Data are in constant terms. This variable, as well as education, is included to investigate the so-called Lipset hypothesis: voters with higher income (and education) are expected to be both more willing and capable to monitor public employees and to take action when the latter violate the law. Then, we expect a negative sign associated to both the coefficients of these variables.

c) School attainment is a proxy for the level of education in the regions, measured as the share of high school enrolment over labour force.

d) Gini index is the regional inequality level, built using micro-data on the households' disposable income. These data come from the Survey of Household Income and Wealth (SHIW) conducted by the Bank of Italy (several years). The rationale is that as voters become more diverse along the income line, they will focus on redistribution rather than on the honesty of government officials (Mauro, 1995; Alesina et al., 1996). We then expect that an increase in income inequality will positively affect the degree of corruption.

e) Current expenditure/GDP and Capital expenditure/GDP capture the role of government size on corruption (and indirectly on growth). ${ }^{6} \mathrm{~A}$ larger government size may generate a potential for corruption by producing more resources to be stolen and more rules to be exploited or subverted. This can be the case for the Italian regions where the public sector plays a quite relevant role in the economy. Corruption alters the composition of government expenditures towards less productive activities and thus the greater the government expenditures the greater the negative effects of corruption (Mauro, 1998, Tanzi and Davoodi, 1998; Gupta et al., 2001).

f) Number of laws enacted by the region is an alternative way to capture the impact of government size on corruption (Weingast et al., 1981).

g) Fragmentation of regional government. When governments consist of large coalitions characterized by a certain number of parties with conflicting interests, the members of the coalition face a prisoner's dilemma with respect to expenditures decisions. Each of the partners within the coalition has different distributional objectives and consequently an incentive to protect the budget share which may favor their own clientele (Roubini and Sachs, 1989a; 1989b). Political fragmentation may then increase the distribution of rents among politicians and engender a higher level of corruption. The use of this variable is also suggested by a change of the regional electoral system that occurred in 1995. The mechanism by which the members of the regional Council are elected switched from a pure proportional representation to a mixed one. A top-up number of seats for the winning coalition is also introduced, so that the absolute majority of the legislators will be held by the coalition linked to the regional list that has obtained the relative majority of the votes. Furthermore, the law reduced the tenure length of the Council from five to two years if the relationship of confidence between the Council and the regional government breaks down during the first two years. This reform was completed in 1999 when it was established that the President of the Region is

\footnotetext{
${ }^{6}$ Since until the late 1990 s regional expenditure was financed through transfers from the central government, we do not include transfers among the independent variables. Nonetheless, we estimated a set of regressions with the inclusion of this variable and the results do not change.
} 
elected by universal and direct suffrage. We measure government fragmentation with the Herfindahl index for concentration. The index is built by using the seats of the majority supporting the regional government with respect to the overall legislature and ranges from 0 (a legislature in which each legislator belongs to a different party) to 1 (when all members belong to the same party). ${ }^{7}$ Data come from the Ministero dell'Interno. On this variable we expect a negative coefficient.

h) The share of Voluntary organizations over the population, the local Diffusion of newspapers and the share of voters that participate in referendums on the total of voters, Referendum voters. These variables proxy the degree of civicness of Italian regions as propensity of citizens to be politically involved and as general attitude towards corrupt practices. These three variables control for the degree of corruption generally 'accepted and tolerated' in each regional environment. FIVOL (Federazione Italiana per il Volontariato) is the source of data on voluntary organizations and the Ministero dell'Interno on the referendum voters. Data on the diffusion of newspapers come from ADS (Agenzia Diffusione Stampa).

The second step consists in estimating the following growth equation:

[2] GDPgrowth $_{\text {it }}=h\left(\right.$ GDPgrowth $_{i t-1}, Y_{i t}$, CORRUPTION_F $\left.F_{i t}, u_{i t}\right)$

for $i=1, \ldots, 20$ and $t=1980, \ldots, 2004$, where $Y$ is a vector of standard economic growth models explanatory variables and $u$ is the error term. Equation [2] substitutes the variables on corruption with the fitted values obtained in step 1, COR_F and COR+ASCR_F.

The dependent variable of Equation [2] is GDPgrowth, the annual growth of GDP per capita as already defined.

As measure of corruption we use the fitted values estimated in equation [1] (CORRUPTION_F).

The vector $Y$ includes a number of socio-economic and socio-demographic variables:

i) The lagged growth level, GDPgrowth ${ }_{i t-1}$. The coefficient of this variable indicates the average regional trend of growth, that is not predictable a priori.

j) Fixed gross public and private investments, Investments/GDP. To avoid reverse causality, we introduce this variable with a one year lag and expect a positive correlation with the GDP.

k) Public consumption/GDP and Private consumption/GDP are expected to be negatively correlated with economic growth.

I) Expenditure/GDP is the total expenditure over the GDP, is expected to be positively correlated with economic growth, if productive.

$\mathrm{m})$ The first difference of the Gini index to capture the effect of a variation of inequality on growth. An unequal distribution of income is a barrier to growth because it generates a pressure to adopt redistributive policies that have an adverse effect on investment (Persson and Tabellini, 1994); present wealth, moreover, may depend on past wealth. Therefore, the more unequal a region is, the lower its growth rate.

\footnotetext{
${ }^{7}$ To calculate this index, we sum the seats of each party $i$ of the majority, calculate the percentage $s$ that these represent on the total number of seats of the Council and compute the Herfindahl index: Fragmentation $=\sum_{i=1}^{N} s^{2}$

where $\mathrm{N}$ is the total number of seats of the Council. We then use the normalized Herfindahl index that ranges from 0 to 1 and is computed as follows: $H^{*}=(H-1 / N) /(1-1 / N)$ where again, $\mathrm{N}$ is the total number of seats of the Council and $\mathrm{H}$ is the usual Herfindahl index, as above.
} 
n) School attainment is a proxy for the level of human capital in the regions, as previously defined.

o) Labour force is the size of the labor force, that is to say the share of units of labor over the regional population. While Labor force is an indicator of the efficiency of the input labor, School attainment measures the quality of the input. We expect a positive sign associated to both these coefficients.

\section{Results}

Table 3 presents the results of the estimation of Equation [1]. Consistently with our predictions, high levels of corruption are associated with low levels of GDP growth and civicness, as the negative coefficients of Voluntary organizations, Diffusion of newspapers and Referendum voters show. The positive sign of the Diffusion of newspapers $t-1$ variable suggests that corruption is sensitive only to current information; in other words, the diffusion of newspapers is not an effective tool against corruption. This outcome seems to be in line with the positive sign on School attainment. Contrary to the prediction of the literature, our estimates show that education does not play a role in reducing corruption. Instead, as it clearly emerged in the so-called Mani Pulite investigation that signed the passing from a system of political patronage to a system of corruption that involved legislators, bureaucrats and businessmen, corruption in the 1980s and 1990s was typically a 'white collar' phenomenon.

Table 3. Estimation of Equation 1

\begin{tabular}{ccc}
\hline & $C O R$ & $C O R+A S C R$ \\
\hline Population & $-0.05^{* * *}$ & -0.017 \\
GDPgrowth & $-0.28^{* * *}$ & $-0.31^{* * *}$ \\
School attainment & $0.3^{*}$ & $0.35^{* *}$ \\
Gini index & -0.09 & 0.46 \\
Current expenditure/GDP & -0.04 & 0.16 \\
Capital expenditure/GDP & 0.08 & 0.053 \\
Number of laws & $0.13^{* *}$ & $0.12^{* *}$ \\
Fragmentation & $0.58^{* * *}$ & $0.63^{* * *}$ \\
Voluntary organizations & $-0.11^{* *}$ & $-0.13^{* * *}$ \\
Diffusion of newspapers & $-0.33^{* * *}$ & $-0.36^{* * *}$ \\
Diffusion of newspapers t-1 & $0.45^{* * *}$ & $0.48^{* * *}$ \\
Referendum voters & -0.06 & -0.07 \\
ASCR, associative corruption & $0.17^{* * *}$ & \\
crimes & $2.88^{* *}$ & $3.35^{* * *}$ \\
Constant & 396 & 399 \\
Observations & 0.485 & 0.413 \\
\hline
\end{tabular}

Note: OLS regression, robust option specified. $C O R=$ individual corruption crimes; $C O R+A S C R=$ sum of all the crimes. Continuous variables in natural log. Significance level: ${ }^{*} p<0.05 ;{ }^{* \star} p<0.01 ;{ }^{* \star *} p<0.001$

The Number of laws and Fragmentation are, as predicted, positively correlated with corruption. Finally, the presence of associative crimes (ASCR) increases the level of individual crimes, bridging the two types of corruption. 
Table 4. Estimates of Equation 2

\begin{tabular}{|c|c|c|c|c|c|c|}
\hline & Model 1 & Model 2 & Model 3 & Model 4 & Model 5 & Model 6 \\
\hline GDP growth $\mathrm{t}-1$ & $0.386^{\star \star \star}$ & $0.313^{\star \star *}$ & $0.665^{\star \star \star}$ & $0.599^{\star \star \star}$ & $0.391^{* * *}$ & $0.335^{\star \star *}$ \\
\hline Expenditure/GDP & & & & & 0.002 & 0.107 \\
\hline Investments/GDP lag & 0.05 & 0.138 & 0.577 & 0.131 & 0.036 & 0.136 \\
\hline $\begin{array}{c}\text { Public } \\
\text { consumption/GDP }\end{array}$ & $-1.22^{* *}$ & $-1.009^{* *}$ & 0.007 & -0.830 & $-1.235^{\star}$ & $-0.991^{*}$ \\
\hline$\Delta$ Gini index & -0.28 & -0.009 & 0.512 & 0.496 & -0.199 & 0.160 \\
\hline School attainment & $0.59^{* *}$ & $0.75^{\star * *}$ & 0.065 & 0.749 & 0.679 & $0.886^{*}$ \\
\hline Labour force & $-2.33^{\star *}$ & $-2.48^{* *}$ & -1.979 & -2.481 & $-2.32^{*}$ & $-2.462^{* *}$ \\
\hline COR_F & $-8.87^{\star \star \star}$ & & & & $-8.36^{\star \star *}$ & \\
\hline COR_F2 & -0.50 & & & & $-0.47^{* * *}$ & \\
\hline$\left(C O R+A S C R \_F\right)$ & & -2.3 & & & & $-2.20^{\star * *}$ \\
\hline$\left(C O R+A S C R \_F\right) 2$ & & $-0.64^{* * *}$ & & & & $-0.58^{\star * *}$ \\
\hline $\begin{array}{c}\text { Expenditure/GDP } \\
{ }^{*} \mathrm{COR} F\end{array}$ & & & -0.254 & & & \\
\hline $\begin{array}{l}\text { Expenditure/GDP } \\
{ }^{*}(\text { COR+ASCR F })\end{array}$ & & & & $-4.51^{* * *}$ & & \\
\hline
\end{tabular}

Note: Dependent variable, natural log of GDP growth. LSDVC estimation initialized with AB estimator, 50 bootstrap repetitions. 396 observations. Continuous variables in natural log. Significance level: ${ }^{*} p<0.05 ;{ }^{* *} p<0.01 ;{ }^{* * *} p<0.001$

Table 4 presents the results of the growth equation using the LSDVC estimator, including the fitted values of the estimation of the corruption equation. ${ }^{8}$ The six models differ with respect to the explanatory variables they consider: models 1 - 4 include the lagged value of investments, while models $5-6$ also analyze the amount of public expenditure as a share of the GDP. Finally, models $3-4$ interact the proxies for corruption with public expenditure to control for their combined effect on growth. ${ }^{9}$ This effect turns out to be negative and significant, suggesting that the presence of corruption nullifies the positive impact that public expenditures, when productive, have on growth. This result emphasizes the 'sanding' impact of corruption.

The variables of interest, i.e. the measures of corruption, are negative and significant as expected. In particular, COR_F and COR+ASCR_F are the elasticity of growth to corruption. A marginal variation of COR_F is associated with an opposite variation of economic growth of about $8 \%$; the effect reduces to $2.2 \%$ for the sum of the crimes. The smaller coefficient associated to COR+ASCR_F indicates that the two types of corruption interact with the economic environment in a way that is complementary and not substitute to the economy itself. Associative crimes, in this perspective, seem to mitigate the impact of corruption on growth.

The hypothesis of a non-linear relationship between corruption and growth has been tested by including the squared variables of corruption. The coefficients, however, do not show a growth-maximizing effect and rather describe a stable negative impact of corruption on growth. In other words, our results suggest that Italy is located on the negative slope of the non-linear relationship after the maximum point as the incidence of corruption is persistently high.

The coefficients associated with the lagged dependent variable indicate a pattern of positive growth that is robust across the estimations. The regions have not yet

\footnotetext{
${ }^{8}$ The LSDVC estimates are robust to the application of the System GMM estimator and the estimation of a first difference IV regressions, instrumenting the lagged dependent variables with the lagged independent variables, and assuming corruption to be exogenous. As already said, the GMM estimation of Equation 2 never satisfies the rule of thumb, as in the most parsimonious specification we use 23 instruments for 19 groups.

${ }^{9}$ The results are robust to the introduction of time effects.
} 
reached a long-term equilibrium path of growth; full convergence is far from being reached. The coefficient on Investments/GDP lag is never significant, probably because the lack of disaggregated data on public and private investment hides large inefficiencies in public investment and generates this unexpected result. ${ }^{10}$ Expenditure/GDP, similarly, is never statistically significant but shows the expected positive sign; public consumption negatively impacts on growth, but the coefficient is significant only in the models excluding the interaction between expenditures and corruption. The first difference of the Gini index, $\Delta G i n i$, is never significant and changes the sign across the models. Interestingly, School attainment is positive and Labor force is negative; both these covariates, however, are significant when lagged investments are included in the specification. The sign of these coefficients is motivated by a larger importance given to the quality of the labor force with respect to its size.

Since government intervention has been the major policy to reduce income differentials between the North and the South of the country, we further investigate the role of public expenditures on economic growth in the Italian regions. ${ }^{11}$ In Table 5 we present the estimation of a set of regression where total expenditure has been disaggregated into its main components ${ }^{12}$, i.e. current and capital expenditure.

The effects of the control variables are consistent with the results of Table 4. The variable Expenditure/GDP is never significant and also its disaggregation is not a significant determinant for growth. In particular, Capital expenditure/GDP fosters growth when controlling for corruption (Model 3), but it is not significant when controlling also for associative crimes (Model 4). This result is unexpected but suggests that the presence of criminal associations in some regions nullifies the productive content of capital investments. ${ }^{14}$ Since local governments have a certain degree of discretion to direct public investments, the efficiency of capital expenditure reasonably changes according to the economic environment where it is implemented. As matter of fact, the composition of crimes varies across observations and some regional economies are more affected by criminal infiltrations than others. Current expenditure/GDP, on the other hand, is usually more rigid as it includes mainly personnel wages, transfers to municipalities and local health units (called ASL). These items are not expected to stimulate growth but to face everyday needs; therefore, the negative but not significant signs we find in Models 3 and 4 do not contradict any theoretical prediction in the literature. In Models $5-8$, where we use the lagged values of expenditure to overcome an eventual simultaneity of expenditure and growth, this pattern is confirmed.

\footnotetext{
${ }^{10}$ The disaggregated series of data on infrastructure expenditure, that better proxies public investment expenditure, is available only until 1991 (Del Monte and Papagni, 2001), and it has not been included in the analyses to avoid such a huge loss of information.

${ }^{11}$ On the nexus between the composition of public expenditure, corruption and growth see, among others, Goel and Nelson (1998), Mauro (1998), Tanzi and Davoodi (1998), Pieroni and D'Agostino (2009).

${ }^{12}$ The results are robust to the introduction of time effects.

${ }^{13}$ To avoid collinearity issues we exclude the lagged investments.

${ }^{14}$ Caruso (2009) shows that in the Italian regions in the period 1997-2003 investments in real estate sector, public investments and health expenditures are positively correlated with corruption, while social protection expenditure and private investments are negatively correlated with corruption.
} 
Table 5. Estimates of Equation 2, disaggregated expenditure

\begin{tabular}{|c|c|c|c|c|c|c|c|c|}
\hline & Model 1 & Model 2 & Model 3 & Model 4 & Model 5 & Model 6 & Model 7 & Model 8 \\
\hline $\begin{array}{c}\text { GDP } \\
\text { growth t-1 }\end{array}$ & $0.397^{\star \star \star}$ & $0.352^{\star \star \star}$ & $0.352^{\star \star \star}$ & $0.307^{\star \star \star}$ & $0.374^{\star \star \star}$ & $0.327^{* \star *}$ & $0.377^{\star \star \star}$ & $0.316^{\star \star \star}$ \\
\hline $\begin{array}{l}\text { Expenditure } \\
\text { /GDP }\end{array}$ & 0.002 & 0.110 & & & & & & \\
\hline $\begin{array}{l}\text { Current } \\
\text { expenditure } \\
\text { /GDP }\end{array}$ & & & -0.412 & -0.253 & & & & \\
\hline $\begin{array}{l}\text { Capital } \\
\text { expenditure } \\
\text { /GDP }\end{array}$ & & & $0.130^{*}$ & 0.093 & & & & \\
\hline $\begin{array}{l}\text { Total } \\
\text { expenditure } \\
\text { /GDP t-1 }\end{array}$ & & & & & -0.104 & 0.012 & & \\
\hline $\begin{array}{l}\text { Current } \\
\text { expenditure } \\
\text { /GDP t-1 }\end{array}$ & & & & & & & -0.040 & -0.013 \\
\hline $\begin{array}{l}\text { Capital } \\
\text { expenditure } \\
\text { /GDP t-1 }\end{array}$ & & & & & & & 0.115 & $0.118^{*}$ \\
\hline $\begin{array}{c}\text { Public } \\
\text { consumpt. }\end{array}$ & $-1.231^{* *}$ & $-0.960^{*}$ & -0.942 & -0.818 & $-1.329^{* *}$ & $-1.026^{*}$ & $-1.263^{* *}$ & $-1.048^{*}$ \\
\hline$\Delta$ Gini index & -0.186 & 0.185 & -0.376 & -0.059 & -0.304 & 0.023 & -0.196 & 0.103 \\
\hline $\begin{array}{l}\text { School } \\
\text { attainment }\end{array}$ & 0.691 & $0.906^{\star *}$ & $0.567^{\star *}$ & $0.748^{\star * *}$ & 0.633 & $0.849^{* *}$ & $0.593^{* *}$ & $0.765^{\star \star *}$ \\
\hline $\begin{array}{l}\text { Labour } \\
\text { force }\end{array}$ & $-2.258^{* *}$ & $-2.286^{* *}$ & $-2.231^{* *}$ & $-2.31^{* * *}$ & $-2.037^{*}$ & $-2.22^{\star \star}$ & $-2.329^{* *}$ & $-2.40^{* * *}$ \\
\hline COR_F & $-8.56^{\star \star \star}$ & & $-8.55^{\star * *}$ & & $-9.4^{* * *}$ & & $-8.39^{* \star *}$ & \\
\hline$\left(C O R \_F\right)^{2}$ & $-0.48^{\star \star \star *}$ & & $-0.48^{\star \star *}$ & & $-0.53^{\star * *}$ & & $-0.47^{\star \star *}$ & \\
\hline $\begin{array}{c}\text { COR+ } \\
\text { ASCR_F }\end{array}$ & & $-2.22^{* * *}$ & & $-2.26^{\star * *}$ & & $-2.32^{\star \star *}$ & & $-2.26^{\star \star *}$ \\
\hline $\begin{array}{c}(\mathrm{COR+} \\
\left.\mathrm{ASCR}^{2} \mathrm{~F}\right)^{2} \\
\end{array}$ & & $-0.58^{* * *}$ & & $-0.62^{\star \star *}$ & & $-0.63^{\star \star *}$ & & $-0.61^{* \star *}$ \\
\hline
\end{tabular}

Note: Dependent variable: In GDP growth. LSDVC estimation initialized with AB estimator, 50 bootstrap repetitions. 396 observations. Continuous variables in natural log. Significance level: ${ }^{*} p<0.05 ;{ }^{* *} p<0.01$; $* * * p<0.001$

The coefficients on COR_F and COR+ASCR_F (Table 5) are consistent with the prediction of the theory and with our previous estimations. They are significantly negative across all the models and show similar coefficients. In particular, as in Table 4, the effect of corruption crimes (Models 1, 3, 5 and 7) is always larger than the effect of the overall crimes (Models 2, 4, 6 and 8). Furthermore, the non-linear terms $\left(C O R \_F\right)^{2}$ and $\left(C O R+A S C R \_F\right)^{2}$ remain negative and significant as well and smaller than the linear ones. The empirical analyses indicate a sound negative effect of corruption on growth which is robust to different specifications of the model. The results do not verify the growth-maximizing hypothesis.

\section{Concluding remarks}

This paper investigates the effects of corruption on economic growth in the Italian regions during the period 1980 - 2004. Using a newly assembled data set that include economic, socio-demographic and politico-institutional variables, we address the potential bias of judicial measure of corruption and the endogeneity issue between corruption and growth by developing a two-step empirical strategy, Our results show a negative correlation between corruption and economic growth that is robust to different specifications of the model and econometric techniques. We further investigate the role of public expenditure on economic growth since government intervention has been traditionally the major policy implemented to reduce income differentials between the North and the South of the country. Total expenditure as well as its main components never turn out to be significant, suggesting that the presence of corruption undermines the positive impact that public expenditure generally has, if productive, on economic growth. 


\section{References}

Acemoglu, Daron and Thierry Verdier (1998) 'Property rights, corruption and the allocation of talent: a general equilibrium approach', Economic Journal 108(450): 1381-1403.

Alesina, Alberto and Romain Wacziarg (1998) 'Openness, Country Size and Government', Journal of Public Economics 69(3): 305-321.

Alesina, Alberto, Sule Ozler, Nouriel Roubini and Phillip Swagel (1996) 'Political instability and economic growth', Journal of Economic Growth 1(2): 189-212.

Andvig, Jens C. and Karl O. Moene (1990) 'How corruption may corrupt', Journal of Economic Behaviour and Organization 13(1): 63-76.

Arellano, Manuel and Stephen Bond (1991) 'Some tests of specification for panel data: Monte Carlo evidence and an application to employment equations', Review of Economic Studies 58(2): 277-297.

Baldacci, Emanuele, Arye L. Hillman and Naoko C. Kojo (2004) 'Growth, Governance, and Fiscal-policy Transmission Channels in Low-income Countries', European Journal of Political Economy 20(3): 517-549.

Blackburn, Keith, Niloy Bose and M.E. Haque (2006) 'The Incidence and Persistence of Corruption in Economic Development', Journal of Economic Dynamics and Control 30(12): 2447-2467.

Blundell, Richard and Stephen Bond (1998) 'Initial conditions and moment restrictions in dynamic panel data models', Journal of Econometrics 87(1): 115143.

Bruno, Giovanni S.F. (2005a) 'Approximating the bias of the LSDV estimator for dynamic unbalanced panel data models', Economics Letters 87(3): 361-366.

Bruno, Giovanni S.F. (2005b) 'Estimation and inference in dynamic unbalanced panel data models with a small number of individuals'. Università Bocconi-CESPRI WP No. 165.

Caruso Raul (2009) 'Spesa Pubblica e Criminalità organizzata in Italia, evidenza empirica su dati Panel nel periodo 1997- 2003', Economia e Lavoro 43(1): 71-88.

CRENOS (2004) Regio-It 1970-2002. Data-base on the Italian regions, University of Cagliari.

Daniele, Vittorio and Paolo Malanima (2007) 'Il prodotto delle Regioni e il divario Nord-Sud in Italia (1861- 2004)', Rivista di Politica Economica 97(2): 267-316.

Davigo, Piercamillo and Grazia Mannozzi (2007) La Corruzione in Italia. Percezione sociale e controllo penale. Bari: Editori Laterza.

Del Monte, Alfredo and Erasmo Papagni (2001) 'Public expenditure, corruption and economic growth: the case of Italy', European Journal of Political Economy 17(1): 1-16.

Del Monte, Alfredo and Erasmo Papagni (2007) 'The determinants of corruption in Italy: Regional panel data analysis', European Journal of Political Economy 23(2): 379-396

Elrich, Isaac and Francis T. Lui (1999) 'Bureaucratic corruption and endogenous economic growth', Journal of Political Economy 107(S6): S270-S293.

Fiorino, Nadia and Emma Galli (2010) 'An analysis of the determinants of corruption: Evidence from the Italian regions', POLIS Working Papers No. 171.

Giardina, Emilio, Marina Cavalieri, Calogero Guccio and Isidoro Mazza (2009) 'Federalism, Part Competition and Budget Outcome: Empirical Findings on Regional Health Expenditure in Italy', MPRA Paper No. 16437. 
Goel, Rajeev K. and Michael A. Nelson (1998) 'Corruption and Government Size: A Disaggregated Analysis', Public Choice 97(1-2): 107-20.

Golden, Miriam and Lucio Picci (2005) 'Proposal for a New Measure of Corruption, Illustrated with Italian Data', Economics \& Politics 17(1): 37-75.

Gyimah-Brempong, Kwabena (2002) 'Corruption, economic growth, and income inequality in Africa', Economics of Governance 3(3): 183-209.

Gupta, Sanjeev, Luiz de Mello and Raju Sharan (2001) 'Corruption and military spending', European Journal of Political Economy 17(4): 749-777.

Hall, Robert E. and Charles I. Jones (1999) 'Why do some countries produce so much more output per worker than others?', Quarterly Journal of Economics 114(1): 83-116.

Huntington, Samuel P. (1968) Political Order in Changing Societies. New Haven, CT: Yale University Press.

Knack Stephen and Philip Keefer (1997) 'Does social capital have an economic payoff? A cross-country investigation', Quarterly Journal of Economics 112(4): 1251-1288.

Klitgaard, Robert (1988) Controlling Corruption. Berkeley: University of California Press.

La Porta, Rafael, Florencio Lopez-de-Silanes, Andrei Shleifer and Robert Vishny (1999) 'The quality of government', Journal of Economics, Law and Organization 15(1): 222-279.

Leff, Nathaniel H. (1964) 'Economic development through bureaucratic corruption', American Behavioral Scientist 8(3): 8-14.

Lui, Francis T. (1985) 'An Equilibrium Queuing Model of Bribery', Journal of Political Economy 93(4): 760-781.

Li, Hongyi, Lixin C. Xu and Heng-fu Zou (2000) 'Corruption, income distribution and growth', Economics and Politics 12(2): 155-182.

Mauro, Paolo (1995) 'Corruption and growth', Quarterly Journal of Economics 110(3): 681-712.

Mauro, Paolo (1998) 'Corruption and the composition of government expenditure', Journal of Public Economics 69(2): 263-279.

Méndez, Fabio and Facundo Sepulveda (2006) 'Corruption, growth and political regimes: Cross country evidence', European Journal of Political Economy 22(1): 82-98.

Myrdal, Gunnar (1989) 'Corruption: its causes and effects', in Arnold J. Heidenheimer, Michael Johnston and Victor T. LeVine (eds) Political Corruption: A Handbook, pp. 953-962. New Brunswick, NJ: Transaction Books.

Padovano, Fabio (2007) The Politics and Economics of Regional Transfers. Cheltenham: Edward Elgar.

Persson, Torsten and Guido Tabellini (1994) 'Is Inequality Harmful for Growth?', American Economic Review 84(3): 600-621.

Pettersson-Lidbom, Per and Matz Dahlberg (2003) 'An Empirical Approach for Evaluating Soft Budget Constraints', Uppsala University, Department of Economics Working Paper Series No. 28.

Pieroni, Luca and Giorgio D'Agostino (2009) 'Military Spending, Corruption and Economic Growth', Peace Economics, Peace Science and Public Policy 14(3). 
Pigliaru, Francesco (2009) 'Persistent regional Gaps and the Role of Social Capital: Hints from the Italian Mezzogiorno's Case'. CRENos Working Paper No. 4.

Putnam, Robert D. (1993) Making Democracy Work: Civic Traditions in Modern Italy. Princeton, NJ: Princeton University Press.

Roodman, David (2009) 'A note on the theme of too many instruments', Oxford Bulletin of Economics and Statistics 71(1): 135-158.

Roubini, Nouriel and Jeffrey D. Sachs (1989a) 'Political and economic determinants of budget deficits in the industrial democracies', European Economic Review 33(5): 903-933.

Roubini, Nouriel and Jeffrey Sachs (1989b) 'Government spending and budget deficits in the industrialized countries', Economic Policy 4(8): 99-132.

Shleifer, Andrei and Robert W. Vishny (1993) 'Corruption', Quarterly Journal of Economics 108(3): 599-617.

Tanzi, Vito and Hamid Davoodi (1998) 'Corruption, Public Investment and Growth', in Hirofumi Shibata and Toshihiro Ihori (eds) The Welfare State, Public Investment and Growth, pp. 41-60. Tokyo: Springer-Verlag.

Weingast Barry R., Kenneth A. Shepsle and Christopher Johnsen (1981) 'The Political Economy of Benefits and Costs: A Neoclassical Approach to Distributive Politics', Journal of Political Economy 89(4): 642-664. 